\title{
Political Apathy: A Worrisome Impediment to Electoral Process in Nigeria
}

\author{
OLUWAGBOHUNMI Margaret Folu Ph.D \\ Department of Social Science Education, Faculty of Education, \\ Ekiti State University, Ado Ekiti, Ekiti State, Nigeria
}

\begin{abstract}
A large number of Nigeria citizens especially the elites seem to have lost interest in voting and have left the exercise for commercial drivers, farmers, market women, artisans, commercial motorcyclists etc. An election in which a large number of people refuse to participate may not reflect the will of the people. This study was conducted to determine causes of political apathy as perceived by secondary school teachers and suggest remedies to the menace. The study adopted descriptive research design with a sample of 400 secondary school teachers selected through multi stage sampling procedure with two research questions and one hypothesis. A self-designed questionnaire titled 'Political Apathy Questionnaire (PAQ)' was the instrument used for data collection. The instrument was validated by experts and tested for reliability with 0.71 coefficients. Data collected were descriptively analysed while the hypothesis was tested using t-test analysis at 0.05 level of significance. Finding of the study revealed that teachers perceived all forms of electoral malpractice and bad governance as some of the causes of political apathy. Finding also showed good governance/leadership and enabling environment for free and fair election among others as perceived remedies to political apathy in Nigeria. The hypothesis showed no significant difference in the causes of political apathy as perceived by male and female secondary school teachers. Based on the findings, it was recommended among others that government and electoral bodies should employ different approaches to enlighten the citizens on the danger of political apathy and the need for active participation in political activities so as to ensure that credible, reputable and responsible citizens emerge as leaders.
\end{abstract}

Keywords: Apathy, politics, impediment, participation, electoral process, democracy

DOI: $10.7176 /$ RHSS/10-4-09

Publication date: February $29^{\text {th }} 2020$

\section{Introduction}

General elections hold once in four years in Nigeria. It is a period every citizen of voting age is expected to exercise their franchise in order to elect reputable people into political offices. One of the values that are vital to the working of democracy is the right to vote and be voted in a free, fair and credible election without intimidation which must be enjoyed by all citizens. Since Nigeria returned to civil rule after long military regimes, the country has been plunged into series of political bouleversement such as election rigging, manipulation of election results, intimidation of voters, assassination of political aspirants/opponents, use of political thus for disruption of electoral processes, casting away of election materials, bribery and corruption, vote buying and use of law enforcement agents in favour of the ruling party. Falade and Orungbemi (2010) argued that true democratic governance is absent in Nigeria because the political culture is characterized by intolerance, intimidation, thuggery, assassination, bitterness, apathy, indolence, money and ethnic politics. Utomi (2019) affirmed that since the re-emergence of democracy in 1999, Nigeria has conducted different elections and they were all marred by varying degrees of malpractice. He added that the electoral process in Nigeria is rendered vulnerable to abuse through massive rigging and other forms of electoral malpractices by political parties especially by those in power as they seek to manipulate the system to serve their partisan interest. Ojo (2014) also stated that violence has become synonymous with Nigeria's political culture such that virtually all elections held so far in the country are violent-ridden.

The first stage of electoral process after registration of voters is nomination of candidates for elective posts. Political parties, party leaders and godfathers carefully screen nominees to ensure that those who are loyal, electable, have political will and can carry out their dictates emerge as party flag bearers and eventual winners. According to Liebowitz and Ibrahim (2013), parties are run by godfathers and barons rather than members and they have clientele networks that are used by the party barons to deliver crowds for rallies and party congresses. Omotoso (2019) added that political participation had been endangered and limited by activities of the godfathers who act like demigods and kingmakers as they appropriate to themselves the special role of determining who occupies government positions in the country and on what terms. Money and special interest have produced politicians who end up doing the will of their wealthy sponsors against the will and interest of the people.

Apathy is a state of indifference, suppression of emotions such as concern, excitement, motivation or passion. It means lack of feeling, emotion, interest or concern about something of great importance (Wikipedia, 2019a). Political apathy means lack of interest in political activities of a country. It is the indifference of an individual to participate in political activities which includes lack of interest in elections, voting or political events. Political apathy is displayed when a citizen of voting age refuses to register, obtain permanent voters card (PVC), belong 
to any political party, vote or participate in electoral process (Wikipedia, 2019b). Observation shows that a large number of Nigeria citizens especially the elites have lost interest in voting and have left the exercise for commercial drivers, farmers, market women, artisans, 'okada' riders, young boys and girls who usually turn out in large numbers to endure the stress of voting on long queues, for long hours under the heat of the sun.

According to Agba (2011), majority of Nigerians currently disapprove the conduct of elections and prefer to remain indoors during the period of voting. Falade (2014) maintained that it is no longer contentious to say that voters apathy exists in Nigeria; voter turnout in the just concluded (2011) general elections had provided a scientific and empirical evidence of the existence of voters apathy and disinterestedness of sections of the electorates in elections. An election in which a large number of people refuse to participate may not reflect the will of the people. Lack of enthusiasm for political participation portends danger for democracy. Such danger according to Emerson (2016) is that a minority will install a government that does not have the interest of the majority in their agenda. Griguoli (2018) posited that a vibrant democracy depends on high turnout of a wellinformed electorate and that many citizens do not take voting seriously, understand the consequences of not voting, are uninformed and vote emotionally instead of logically.

Many factors are observed to be responsible for political apathy such as political thuggery, intimidation, believe that votes would not count, insecurity at polling units, vote buying, election rigging, result manipulation and destruction of election materials. Other reasons appear to be lack of trust in government, failure to fulfill electioneering promises, eleventh hour postponement, declaring election inconclusive and delay in release of election results. In interviews conducted with political experts on low turnout, Adedigba (2019) gathered that most people believed their vote would not count and that nature of politics, fear of violence, people not being contented with the system and inability to have access to basics of life were major factors for the low turnout. In Yakubu (2019), Chief Tunde Adeniran, a former Minister and Ambassador maintained that declaring elections inconclusive is nationally embarrassing, unpleasant, damaging and inimical to democracy. Many people also seem to have lost hope of a better government due failure to provide good leadership and violence during campaigns/elections that usually result in death of people. .

According to Yakubu (2012) political obligations of the citizens to the state include voting during elections but there are many political deviants who fail to vote at elections due to leaders' incompetence in their obligations and have experienced that their votes do not matter in producing elected officers due to election malpractices. Yakubu (2012) also observed a declining interest of Nigerians to register and vote from 1999 to 2011 and concluded that bad governance makes people less concerned about their political affairs. Froiland (2015) opined that a relatively high rate of eligible voters do not vote or vote irregularly and that youth apathy plays a significant role in their low voter turnout.

In a report put together by Utomi (2019), it was maintained that an election is said to be credible when it is organized in an atmosphere of peace devoid of rancor and acrimony, the outcome of which must be acceptable to a majority of the electorate and within the international community. Staino (2007) stressed that for voters to participate, they must have full trust in the electoral process, confidence in the overall outcome of the voting exercise and confidence in the way in which those who don't deliver can be voted out etc. Utomi (2019) also suggested basic conditions necessary to create an enabling environment for holding free and fair elections as an honest, competent and non-partisan electoral body, knowledge and willingness of the political community to accept basic rules and regulations governing the contest for power and an independent judiciary to interpret electoral laws and settle election disputes.

From observation, the elites i.e. the educated, the learned, most government workers, teachers, nurses, lecturers etc. no longer deem it necessary to partake in electoral activities. Adeoluwa (2017) affirmed that the electoral process in Nigeria is bedeviled with a lot of irregularities and there seems to be some apathy among the educated elites towards the electoral process. Wikipedia (2019c) maintained that voter apathy of lack of interest is often cited as a cause of lower turnout among eligible voters. Being politically apathetic by the elites in Nigeria has negative influence on the system of government as it allows greedy politicians to keep winning elections and being elected; gives room for high level of corruption, lawlessness and slow development among others. Olawale (2018) opined that one of the effects of political apathy is continued imbalance of power that can lead to civil war and revolution.

Voter apathy is not peculiar to Nigeria alone. In America according to Wikipedia (2019c), the percentage of Americans eligible to vote who did vote was $63 \%$ in $1960,62 \%$ in 2008 , and $55.7 \%$ in 2016 . Wikipedia (2019c) also found that in a USA Today poll taken in $2012,59 \%$ of the citizens chose not to vote because they believed that "nothing ever gets done in government", 54\% believed there was corruption while $37 \%$ admitted that politics did not make any difference in their lives and that is why they choose not to vote. In a study conducted at Nelson Mandela Metropolitan University, South Africa by Breakfast, Bradshaw and Haines (2017), it was found that young people in post-apartheid South Africa have no interest in politics which suggests that political apathy does exist amongst the students.

The rate at which voter turnout decreases in Nigeria elections since 1999 is worrisome. Yakubu (2012) 
observed that out of the $57,938,945$ voters that registered in Nigeria in 1999 , only $30,280,052$ voted. He added that even for the number of people that voted, their votes did not count in many parts of the country due to rigging which allowed unpopular, dictatorial, unrepresentative and irresponsible leaders to emerge. While supporting this, Falade (2014) reiterated that $35 \%$ of the 70 million registered voters took part in 2011 general elections. According to Adedigba (2019), despite the record number of 72,775,585 permanent voters cards (PVCs) collected by registered voters across the country for 2019 elections as declared by the Independent National Electoral Commission (INEC), the overall turnout of voters was 28,614,190 (35.6\%). In Adedigba's (2019) analysis, it was quoted that voter turnout from 1999 to 2019 in Nigeria was 52.3\% in 1999, 69.1\% in 2003, 57.4\% in 2007, 53.7\% in $2011,43.6 \%$ in 2015 and $(35.6 \%)$ in 2019.

Low level of political participation does not exempt women. From observation, women participation in electoral process is low compared to men. Benneth and Benneth (1989) believed that although women vote in national elections at the same rate as men, they are still less politically interested than men. Kostelka, Blais and Gidengil (2018) found in their empirical analysis that although there is generally no gender gap in first-order elections, women tend to vote less than men in second-order contests; this reflects women's weaker interest in politics. According to Wang (2013), conscientiousness and emotional stability can significantly increase female turnout but have no effect on male turnout; as openness to experience increases, men become more likely to vote whereas women become less likely to cast their ballots. Falade (2014) also found that there was effect of gender on political participation as $30 \%$ of men and $13 \%$ of women were highly involved in political activities while $38 \%$ of men and $12 \%$ of women were regularly involved in voting exercise.

Low turnout during elections has become an abysmal situation that calls for urgent action in Nigeria. Some political experts interviewed by Adedigba (2019) however suggested good governance as a way to gain peoples' trust and ensure their participation in Nigeria. Ellis, Gratschew, Pammette and Thiessen (2006) argued that cross national studies have generally found that countries with institutionalised compulsory voting experience high turnout as long as compulsion is backed by effective sanctions for non-voting. Daily Excelsior (2019) stressed that there are democracies where voting is compulsory and regulated by national constitutions and electoral laws; sanctions, penalties, or punishment are provided for non-voting as a civic offence. Daily Excelsior further gave examples of Brazil where failure to vote carries fines except for illiterates and the elderly above 75 years of age; Singapore where non-voters are removed from contesting elections and India where NOTA (none of the above) is included after listing names of candidates for the benefit of voters not in favour of any candidates. It was also noted that NOTA votes may increase if compulsory voting is enforced. Birch (2009) and Umbers (2018) suggested compulsory voting as one of the most effective means of raising turnout with the assertion that it would lead to improvements in political, social and procedural fairness. In view of the above, this study was conducted among secondary school teachers to determine the perceived causes of political apathy and suggest strategies for reducing it in Nigeria. Teachers were considered due to the fact that they are all educated, they are large in number, they are government workers and their action or inaction can have great influence on the political process and the society.

\section{Purpose of the Study}

The purpose of this study was to:

i) determine the causes of political apathy as perceived by secondary school teachers.

ii) suggest strategies for reducing political apathy

\section{Research Questions}

The following questions were raised for the study:

i) What are the causes of political apathy as perceived by secondary school teachers?

ii ) What are the suggested strategies for reducing political apathy in Nigeria?

\section{Research Hypothesis}

There is no significant difference in the causes of political apathy as perceived by male and female secondary school teachers.

\section{Research Methodology}

Research Design: Descriptive research design of the survey type was adopted for the study.

Sample and Sampling Technique: The sample consisted of 400 teachers selected from eight local government areas in Ekiti State through multi stage sampling procedure. Two senatorial districts were first selected. Four Local Government Areas were sampled from each senatorial district using simple random sampling technique. Fifty teachers were randomly selected from each local government using simple random sampling technique.

Research Instrument: The instrument used was a questionnaire titled 'Questionnaire on Political Apathy (QPP)'. The instrument which was designed by the researcher had two sections: section A for bio-data of the respondents 
and B for items on political apathy (causes and strategies for reduction).

Validity and Reliability of the Instrument: The instrument was validated by experts in social sciences and tested for reliability through test-retest method that yielded 0.71 coefficients which was considered high enough to make the instrument reliable. Administration of the Instrument: administration of the instrument was carried out by the researcher with the assistance of one research assistant.

Data Analysis: Data collected were analysed using frequency counts and percentages for descriptive analysis and t-test for the hypothesis. The hypothesis was tested at 0.05 level of significance.

\section{Results}

Research Question 1: What are the causes of political apathy as perceived by secondary school teachers? Table 1: Perceived causes of political apathy

\begin{tabular}{|c|c|c|c|c|c|}
\hline \multirow[t]{2}{*}{$\mathbf{S} / \mathbf{N}$} & \multirow[t]{2}{*}{ Items } & \multicolumn{2}{|l|}{ Agree } & \multicolumn{2}{|c|}{ Disagree } \\
\hline & & Freq. & $\%$ & Freq. & $\%$ \\
\hline 1. & Militarisation of election & 318 & 79.5 & 82 & 20.5 \\
\hline 2. & Bad governance/leadership & 364 & 91 & 36 & 09 \\
\hline 3. & Lack of interest in political activities & 285 & 71.2 & 115 & 28.8 \\
\hline 4. & Lack of trust in the electoral body/process & 323 & 80.8 & 77 & 19.2 \\
\hline 5. & All forms of electoral malpractice & 372 & 93 & 28 & 07 \\
\hline 6. & Declaring election inconclusive & 273 & 68.2 & 127 & 31.8 \\
\hline
\end{tabular}

Table 1 above shows that $93 \%$ and $91 \%$ of the respondents perceived all forms of electoral malpractice and bad governance as causes of political apathy. Lack of confidence in the electoral body and militarization of election were perceived to be causes of political apathy by $80.8 \%$ and $79.5 \%$ respectively while lack of interest in political activities was also agreed on by $71.2 \%$ of the respondents.

Research Question 2: What are the strategies for reducing political apathy in Nigeria?

Table 2: Strategies for reducing political apathy

\begin{tabular}{|c|c|c|c|c|c|}
\hline \multirow[t]{2}{*}{$\mathbf{S} / \mathbf{N}$} & \multirow[t]{2}{*}{ Items } & \multicolumn{2}{|l|}{ Agree } & \multicolumn{2}{|c|}{ Disagree } \\
\hline & & Freq. & $\%$ & Freq. & $\%$ \\
\hline 1. & Compulsory voting & 120 & 30 & 280 & 70 \\
\hline 2. & Truly independent and non-partisan electoral body & 293 & 73.2 & 107 & 26.8 \\
\hline 3. & Removal of all forms of electoral malpractice & 348 & 87 & 52 & 13 \\
\hline 4. & Good governance/leadership & 377 & 94.2 & 23 & 5.8 \\
\hline 5. & Enabling environment for credible, free and fair election & 363 & 90.7 & 27 & 9.3 \\
\hline
\end{tabular}

Table 3 shows that $94.2 \%$ and $90.7 \%$ of the respondents perceived good governance/leadership and enabling environment for credible, free and fair election as solutions to political apathy in Nigeria. Large number of the respondents $(87 \%)$ agreed on removal of all forms of electoral malpractice, $73.2 \%$ agreed on truly independent and non-partisan electoral body while $70 \%$ disagreed on compulsory voting as means of reducing political apathy. Hypothesis 1: There is no significant difference in the perceived causes of political apathy between male and female secondary school teachers.

Table 3: Causes of political apathy as perceived by male and female secondary school teachers

\begin{tabular}{|l|c|l|l|l|l|l|}
\hline Sex & $\mathrm{N}$ & Mean & Std. Deviation & $\mathrm{df}$ & $\mathrm{t}_{\mathrm{cal}}$ & \multicolumn{1}{|c|}{ Decision } \\
\hline Male & 181 & 33.2 & 4.52 & & & \\
Female & 219 & 33.16 & 4.57 & 398 & 0.36 & Not Sig. \\
\hline
\end{tabular}

Table 3 reveals that $t_{c a l}(0.36)$ is not significant at 0.05 level of significance. The hypothesis which states that there is no significant difference between male and female teachers' perception of the causes of political apathy is therefore accepted. This implies that there is no significant difference in the causes of political apathy as perceived by male and female secondary school teachers.

\section{Discussion}

Finding of this study has revealed that bad governance/leadership and all forms of electoral malpractice were perceived as causes of political apathy by secondary school teachers. This finding agrees with Yakubu (2012) and Utomi (2019) respectively. Perception of bad governance/leadership as a cause can be due to peoples' experience under past administrations that failed to fulfill electioneering promises. For example, bad roads have become death traps through which several lives are host on daily basis due to accidents, inadequate finding of education, ill equipped health facilities, increasing unemployment rate among others are factors that do not portray a good government. On electoral malpractice, Utomi (2019) declared that since the re-emergence of democracy in 1999, Nigeria has conducted different elections and they were all marred by varying degrees of malpractice. Yakubu (2012) stressed that people failed to vote because they have lost confidence in the state following its failure to fulfill obligations and concluded that bad governance makes people less concerned about their political affairs. 
The study revealed that a large number of the teachers agreed that other causes of political apathy are lack of confidence in the electoral body and militarisation of election. These findings agree with Yakubu (2019), Wikipedia (2019b) and Adedigba (2019). Lack of confidence in the electoral body can be attributed to the belief that election results could be cancelled, manipulated, falsified or declared inconclusive. Fear of sustaining injury or being killed through stray bullet could be adduced for their agreement on militarisation of election as one of the causes. This finding was also in consonance with the declaration of Adeniran in Yakubu (2019) that it was the over-deployment of soldiers to polling areas that accounted for the gross voter apathy that was recorded in the elections in some parts of the country. Lack of interest could be due to stress caused by queuing for long hours under the heat of the sun, fear of threat from political thugs that could lead to violence or the belief that election could be rigged in favour of an unpopular candidate.

The study also revealed good governance/leadership as remedy to political apathy as perceived by the respondents. This finding agrees with Adedigba (2019) who believed that good governance is a way to gain peoples' trust and ensure active participation in electoral process. It is not unexpected that the respondents suggested removal of all forms of electoral malpractice as another way out of the problem. This can be attributed to the belief that it is only when good governance is instituted and properly injected into the political system and all rules and regulations guiding electoral processes are strictly obeyed by all stakeholders that a larger percentage of the eligible voters can actively participate in political activities. Creation of an enabling environment for credible, free and fair election was also perceived as another remedy to political apathy in Nigeria. This finding corresponds with Utomi (2019) who claimed that an election can be credible only when it is organised in an atmosphere of peace devoid of rancor and acrimony.

Another finding from the study showed that the respondents disagreed on compulsory voting as a remedy to political apathy. This finding disagrees with Birch (2009), Ellis, Gratschew, Pammett and Thiessen (2016) and Umbers (2018) who suggested compulsory voting in their various works as the most effective means of raising voter turnout. This finding can be attributed to the fact that a government that has failed in its obligations to the citizens, involved in electoral fraud and makes lawlessness its watchword will not have any moral justification to enforce compulsory voting on its people. It must be noted that if government succeeds in introduction of compulsory voting, it must be ready for increased void votes. The hypothesis revealed no significant difference between male and female teachers' perception of the causes of political apathy. This finding negates the finding of Wang (2013) and Kostelka, Blais and Gidengil (2018) who found that men show much interest in politics than women. This finding implies that all the teachers irrespective of sex have the same experience of political activities and as such have the same perception of the causes of political apathy in Nigeria.

\section{Conclusion}

From this study, it can be concluded that bad governance, electoral malpractice, lack of confidence in the electoral body and militarisation of election were the perceived causes of political apathy in Nigeria. The perceived remedies were good governance/leadership, enabling environment for credible, free and fair election as well as removal of all forms of electoral malpractice while compulsory voting was not supported by the respondents.

\section{Recommendations}

Based on the findings of this study, the following recommendations were made:

i) Government and electoral bodies should employ different approaches to enlighten the citizens on the danger of political apathy and the need for active participation in political activities so as to ensure that credible, reputable and responsible citizens emerge as leaders.

ii) rules guiding elections and all electoral processes must be strictly followed by all stakeholders in order to remove fear, threat, rigging, violence, killings and malpractices that usually accompany elections

iii) all citizens of voting age must be alive to their political obligations

\section{References}

Adedigba, A. (2019). Analysis: Lagos and the problem of low voter turnout in Nigerian elections. Premium Times Online. Retrieved from www.premiumtimeng.com on $27^{\text {th }}$ July.

Adeoluwa, O.V. (2017). Education for economic emancipation: the case against our case. A lead paper presented at the $1^{\text {st }}$ National Conference of the Faculty of Education, Ekiti State University, Ado Ekiti on Tuesday $11^{\text {th }}$ July.

Agba, M. S. (2011) Political thuggery and democratic dividends in Nigeria: an empirical study. Higher Education of Social Science. 1(1), pp. 58-65.

Bennett, L.L.M. \& Bennett, S.E. (1989). Enduring gender differences in political interest: the impact of socialization and political dispositions. American Politics Research. Retrieved from http://journals.sagepub.com on $18^{\text {th }}$ January, 2020.

Birch, S. (2009). The case for compulsory voting. Public Policy Research, 16(1), 21-27. Wiley Online Lib. rary 
https://onlinelibrary.wiley.com retrieve $1^{\text {st }}$ May 2019.

Breakfast, N.B, Bradshaw, G. \& Haines, R. (2017). Political apathy amongst students: a case study of Nelson Mandela Metropolitan University. Africa's Public Service Delivery and Performance Review 5(1). http://doi.org/10.4102/apsdpr.u5il.172

Daily Excelsior (2019). Voter apathy causes and remedies. Retrieved from www.dailyexcelsior.com on $27^{\text {th }}$ September.

Ellis, A; Gratschew, M. Pammett, J. H. \& Thiessen, E. (2006). Engaging the electorate: initiatives to promote voter turnout from around the world. International Institute for Democracy and Electoral Assistance 2006. Sweden: Publications Office International IDEA SE-103 34 Stockholm.

Emerson, D. (2016). What are the dangers of political apathy? From www.quira.com on $20^{\text {th }}$ April.

Falade, D.A. (2010). Political participation in Nigerian democracy: a study of some selected local government areas of ondo state, Nigeria. Global Journal of Human-Science: F Political Science. 14(8), Version 1. Retrieved from----- on $20^{\text {th }}$ January, 2020.

Falade, D.A \& Orungbemi, O. (2010). Democratic governance and political education in Africa. A paper presented at the 3rd International Conference on Forgotten Africa and African Renaissance at the Treasure land Conference Centre, Kumasi-Ghana from $12^{\text {th }}$ to $16^{\text {th }}$ October, 2010.

Froiland, J. M. (2015) Political apathy and youth. EBSCO Research starters; Salem press Encyclopedia. Ipswich, MA: EBSCO

Griguoli, F. (2018). Dear Americans: why don't more of you vote? Online Tribune, March 23.

Kostelka, F; Blais, A, \& Gidengil, E. (2018). Has the gender gap in voter turnout really disappeared? West European Politics.doi.10.1080/0102382.2018.1504486. Retrieved from www.researchgate.net on $19^{\text {th }}$ January, 2020.

Liebowitz,, J. \& Ibrahim, J. (2013). A capacity assessment of Nigerian political parties. A Democratic Government for Development (DGD) Programme, UNDP, Nigeria 1-67.

Ojo, O.M. (2014). Electoral security and democratic consolidation in Nigeria. In Ikuejube, G. and Olupayimo, D.Z. (eds) Nigeria's Internal Security Challenges: Strategies for Sustainable Development, Ibadan, John Archers, $1-28$

Olawale, J. (2018). Reasons for political apathy in Nigeria. Retrieved from www.legit.ng on $2^{\text {nd }}$ October.

Omotoso, O. F. (2019). Politics of power and power of politics: the anatomy of Nigerian government and politics. The $56^{\text {th }}$ inaugural lecture in Ekiti State University, Tuesday $10^{\text {th }}$ September.

Staino, S. (2007). Voter apathy and revival of genuine political participation. Retrieved from aceproject.org on $27^{\text {th }}$ September, 2019.

Umbers, L. M. (2018). Compulsory voting: a defence. British Journal of Political Science, Cambridge

Utomi, J. (2019). Opinion: elections in Nigeria, then, now and the future. Retrieved from legit.ng.online on $26^{\text {th }}$ April.

Wang, C.H. (2013). Gender differences on the effect of personality traits on voter turnout. Electoral Studies 34. Doi;10.1016/electoralstudies 2013.10.005. Retrieved from www.researchgate.net on $19^{\text {th }}$ January, 2020.

Wikipedia. (2019a). Apathy. Retrieved from en.m.wikipedia.org on $14^{\text {th }}$ April.

Wikipedia. (2019b). Political apathy. Retrieved from en.m.wikipedia.org on $20^{\text {th }}$ April.

Wikipedia. (2019c). Voter apathy. Retrieved from en.m.wikipedia.org on $20^{\text {th }}$ April.

Yakubu, Y. A. (2012). Democracy and political apathy in Nigeria (1999-2011). European Scientific Journal 8(20), $38-48$.

Yakubu, D, (2019). Between 2015 and 2019 elections: questions Adeniran wants Nigerians to ask. Vanguard, April 20. From www.vanguardngr.com on $20^{\text {th }}$ April. 